\title{
PERAN PRANATA ADAT DALAM PENCEGAHAN KONFLIK ANTARA KELOMPOK MASYARAKAT ADAT
}

\author{
I Putu Agus Arya Dauh, I Ketut Sukadana, I Made Minggu Widyantara \\ Fakultas Hukum Universitas Warmadewa, Denpasar-Bali, Indonesia
}

\begin{abstract}
Abstrak
Tatanan adat menjadi aspek sosiologis dari peran kelembagaan tata cara dalam penanganan konflik merupakan kenyataan yang masih ada dalam masyarakat Indonesia. Masyarakat Indonesia secara garis besar masih menerapkan nilai-nilai adat yang sudah diterapkan sejak dulu sebagai panutan dalam hidup bermasyarakat. Undang-Undang Nomor 7 Tahun 2012, telah mendorong tatanan adat dalam pengelola beserta menyelesaikan permasalahan di masyarakat. Permasalahan yang akan dibahas dalam penulisan ini adalah pengaturan penanganan konflik sosial di Indonesia menurut Undang-Undang No. 7 Tahun 2012 dan peran pranata adat dalam penanganan konflik sosial dalam masyarakat heterogen Indonesia. Pada penelitian ini penulis menggunakan metode penelitian hukum normatif. Pengkajian ini bisa dikatakan memakai pendekatan sosio hukum. Hasil Penelitian ini memperlihatkan bahwa pengaturan penanganan konflik sosial menurut Undang-Undang No. 7 tahun 2012 Pranata Adat memiliki peranan dalam upaya pencegahan konflik, penanganan konflik, dan penanganan pasca konflik antar masyarakat. Peran tatanan masyarakat adat dalam penanganan suatu konflik bagi kelompok masyarakat Indonesia meningkatkan atau menumbuhkan sikap toleransi dan saling menghormati kebebasan dalam menjalankan kegiatan bermasyarakat. Dengan tumbuhnya rasa toleransi, maka konflik antar masyarakat dapat dihindarkan.
\end{abstract}

Kata Kunci: Kelompok Masyarakat; Pencegahan Konflik; Pranata adat

\begin{abstract}
Customary order becoming a sociological aspect of institutionalized procedures for handling conflicts is a reality that still exists in Indonesian society. Indonesian people in general still apply the traditional values that have been applied for a long time as role models in social life. Law Number 7 of 2012, has encouraged customary arrangements in the management and solved problems in the community. The issue to be discussed in this paper were the regulation of handling social conflicts in Indonesia according to Law No. 7 of 2012? and the role of traditional institutions in handling social conflicts in Indonesia's heterogeneous society. In this study the authors used a normative legal research method. This study use the socio-legal approach. The results of this study showed that the regulation of handling social conflicts according to Law No. 7 of 2012 Customary Institutions have a role in conflict prevention, conflict management, post-conflict handling between communities. The role of the customary community order in handling a conflict for Indonesian community groups increases or fosters tolerance and mutual respect for freedom in carrying out community activities. With the growth of tolerance, conflict between communities can be avoided.
\end{abstract}

Key Words: Community Groups, Conflict Prevention, Customary Institutions

\section{PENDAHULUAN}

Masyarakat hukum adat merupakan sekelompok manusia yang memiliki tata susunan tetap, memiliki pengurus, harta benda dan bertindak sebagai satu kesatuan terhadap dunia luar yang mendiami suatu wilayah (Soepomo, 2000). Pranata adat mencakup lembaga dan aturan yang dipergunakan oleh masyarakat hukum adat dalam menciptakan tata kehidupan masyarakat yang tertib, aman dan teratur. Aturan ini terdapat dalam masyarakat hukum adat yang bentuknya tidak tertulis.

Pencegahan konflik merupakan upaya yang dilakukan dalam mencegah suatu konflik dengan meningkatkan penerapan UU dan penyesuaian dengan tatanan adat. Perselisihan antar masyarakat sedapat mungkin diselesaikan dengan segera, sehingga tidak menimbulkan keresahan yang menimbulkan sengketa di masyarakat. Konflik bersifat fungsional secara positif dan negatif (Hussein \& Al-Mamary, 2019). Umumnya konflik bersifat negatif yang terjadi di masyarakat adalah dapat 
merugikan masyarakat karena mengganggu keharmonisan tata kehidupan masyarakat. Sedangkan konflik yang bersifat positif adalah konflik yang dapat diselesaikan dengan baik sehingga dapat memperbaiki tata kehidupan masyarakat ke arah yang lebih baik dari kehidupan yang sebelumnya.

Penegakan hukum adat diatur dalam sistem peradilan adat yang dijalankan oleh Lembaga adat agar hukum adat berlaku efektif (Manarisip, 2012). Tatanan adat diatur dalam Pasal 40 UU No. 7 Tahun 2012, dimana merupakan peran kelembagaan tata cara dalam penanganan konflik sosial. Penyelesaian konfik sosial di daerah sebaiknya dilakukan dengan mekanisme melalui Lembaga adat. Ketika mekanisme adat telah ditempuh, pemerintah dan semua pihak harus mengakui hasil dari penyelesian konflik dengan mekanisme pranata adat ini. Namun bila mekanisme yang dilakukan melalui Lembaga adat tidak berhasil, barulah ditempuh melalui mekanisme lainnya.

Pengakuan kelembagaan adat dalam UU No. 7 Tahun 2012 belum maksimal karena dalam peraturan ini hanya mengakui Lembaga adat yang masih ada, dan peraturan ini tidak mengamanatkan upaya untuk mengembangkan kearifan lokal dalam upaya penyelesaian konflik sosial. Namun dalam Undang- Undang No. 6 Tahun 2014 tentang Desa mengatur ketentuan untuk memperkuat Lembaga adat dalam melaksanakan fungsi-fungsi Lembaga adat termasuk fungsi penyelesaian sengketa (Samsul, 2014).

Berdasarkan latar belakang di atas, penelitian ini dilakukan dengan tujuan mendeskripsikan pengaturan penanganan konflik sosial di Indonesia menurut Undang-Undang No. 7 Tahun 2012 dan menguraikan peran pranata adat dalam penanganan konflik sosial dalam masyarakat heterogen Indonesia.

\section{METODE PENELITIAN}

Penelitian ini didesain dengan menggunakan tipe penelitian hukum normatif. Jenis penelitian ini menganalisis dan mengkaji hukum sebagai pengaturan dan norma sebagai acuan dalam menyusun sistem perundang-undangan yang mengatur mengenai kehidupan bermasyarakat (Soekanto \& Mamuji, 1990). Pendekatan yang digunakan dalam studi ini adalah pendekatan sosio hukum (socio-legal), pendekatan perundang-undangan, dan pendekatan konseptual. Sumber data penelitian ini adalah bahan hukum primer dan sekunder. Sumber bahan hukum primer diperoleh dari perundang- undangan yakni UUD NKRI Tahun 1945 dan UU No. 7 Tahun 2012. Teknik pengumpulan sumber bahan hukum primer dan sekunder menggunakan teknik pencatatan, membaca buku-buku, peraturan perundang- undangan dan literatur lainnya yang ada kaitannya dengan permasalahan yang penulis bahas. Metode analisis yang digunakan dalam pengkajian ini adalah metode kualitatif. Dengan menggunakan analisis norma hukum positif tersebut, maka asas-asas hukum bisa ditemukan yang merupakan doktrin-doktrin serta asas-asas yang dijelaskan dalam norma-norma, sehingga simpulan dapat dibuat berdasarkan hasil analisis tersebut (Fajar \& Ahmad, 2010).

\section{HASIL DAN PEMBAHASAN}

\section{Pengaturan Penanganan Konflik Sosial di Indonesia Menurut Undang-Undang No. 7 Tahun 2012}

Pranata adat adalah tingkatan pengetahuan mengenai kebenarannya, serta diawasi oleh pemimpin dalam membuat aturan (Armida, 2010). Pelaksanaan dan penerapan sanksi bagi masyarakat yang melanggar aturan telah disepakati bersama dalam kelompok masyarakat tertentu. Sekelompok masyarakat yang mempunyai tiga dimensi sosial disebut dengan masyarakat adat. Masyarakat adat merupakan sekelompok masyarakat yang memiliki sistem nilai, ideologi, ekonomi, politik, budaya, dan wilayah sendiri yang telah menetap secara turun temurun dalam satu wilayah geografis tertentu (Mulyadi, 2013).

Pranata adat memiliki prinsip yang berbeda-beda dalam menangani konflik, terutama pencegahan dan penghentian dalam kekerasan konflik. Hakikat ini harus sesuai dengan tiga dimensi sosial, namun dalam masyarakat adat satu dan lainnya memiliki diemensi sosial yang berbeda. Masyarakat adat dalam hukum Indonesia mengharuskan prinsip selaras dengan hukum yang berlaku (Manarisip, 2012). Banyak pelaksanaan antara prinsip dan hukum positif tidak berjalan selaras karena mempunyai konflik.

Dalam hukum positif fungsi tatanan adat kurang maksimalnya karena kewenangan pranata adat kurang diatur dalam menangani kasus konflik sosial antar anggota (Tamarasari, 2002). Oleh karena itu, peraturan diperlukan untuk mengatur secara khusus mengenai fungsi pranata adat yang disesuaikan dengan sistem hukum Indonesia. 
Banyaknya konflik sosial yang terjadi di masyarakat menyebabkan pemerintah mengeluarkan Undang-Undang No. 7 Tahun 2012 tentang Penanganan Konflik yang mengatur tentang upaya penanganan konflik. Peraturan ini lahir atau dibangun kajian penyelarasan dan pengharmonisasian dengan pengaturan lain berkaitan dengan Penanganan Konflik Sosial. Upaya melakukan penanganan konflik sosial sesuai Pasal 6 ayat (1) Undang-Undang No. 7 Tahun 2012 tentang Penanganan Konflik Sosial yakni dengan menggunakan sistem penyelesaian perselisihan secara damai, meredam potensi konflik, menjaga situasi damai dalam masyarakat, dan memiliki sistem peringatan dini kepada masyarakat. Sejak cita-cita kesejahteraan negara dilakukan, pemerintah bersungguh-sungguh melakukan campur tangan terhadap interaksi kemasyarakatan demi kepastian hidup yang didapat oleh masyarakat. Sebab itu, fungsi awal pemerintah yang bersifat represif mulai berubah sedikit demi sedikit dan bertambah dengan fungsi lainnya yang bersifat melayani (Prawirohardjo, 1993).

\section{Peran Pranata Adat dalam Penanganan Konflik Sosial dalam Masyarakat Heterogen Indonesia}

Tatanan adat merupakan kelembagaan yang dihormati yang lahir dari nilai adat, dipercaya oleh masyarakat dalam melakukan penanganan konflik sosial antar kelompok masyarakat (Salim, 2016). Hal ini diatur dalam Pasal 41 Undang-Undang No. 7 Tahun 2012 yang dimana bahwa Kelembagaan penyelesaian konflik terdiri atas Pemerintah, Pemerintah Daerah, Pranata Adat dan/atau Pranata Sosial, serta Satuan Tugas Penyelesaian Konflik Sosial. Penyelesaian konflik melalui pranata adat difasilitasi oleh Pemerintah Daerah dengan melibatkan aparatur daerah.

Pemberdayaan pranata adat dikaitkan dengan Undang-Undang Nomor 7 Tahun 2012 tentang Penanganan Konflik Sosial dalam kasus Bali. Bahkan pada perda Provinsi Bali Nomor 3 Tahun 2003 yang telah diganti dengan Peraturan Daerah Provinsi Bali Nomor 4 Tahun 2019 Pasal 1 yang berbunyi Prajuru Desa Adat adalah Pengurus Desa adat yang mengatur peran Prajuru desa (Pengurus desa Adat) untuk memiliki tugas-tugas dalam mengusahakan perdamaian dan penyelesaian sengketasengketa/konflik secara adat. Jadi, sebelum Undang- Undang Penanganan Konflik sosial lahir, Bali sudah lebih awal memiliki solusi struktural yang memanfaatkan potensi kultural (adat) (Suardita \& Krisnawati, 2015).

Kelembagaan pemerintahan Desa Adat yakni Prajuru Desa Adat, Sabha Desa Adat, Kerta Desa Adat, Banjar Adat / Banjar Suka Duka, hal ini tercantum dalam Pasal 28 ayat (2) Peraturan Daerah Provinsi Bali Nomer 4 Tahun 2019. Prajuru adat merupakan tokoh yang dihormati oleh masyarakat dan krama desa atau anggota desa lebih patuh kepada apa yang disampaikan oleh prajuru desa daripada pihak kepolisian yang bertugas meredam konflik. Penyelesaian konflik dalam desa adat melalui kelembagaan adat dengan mekanisme awig-awig (peraturan desa) umumnya lebih efektif daripada mekanisme lain (Sudantra, 2009). Hal ini terjadi karena terdapat foktor-faktor yang menyebabkannya, yakni warga desa adat pada umumnya sangat patuh terhadap awig-awig (peraturan desa). Penyelesaian dengan musyawarah dan mufakat merupakan ciri penyelesaian sengketa adat, sehingga dapat mengakomodasikan kepentingan-kepentingan para pihak yang dapat dikatakan hasilnya menguntungkan para pihak yang bersengketa.

Peraturan Prajuru Desa Adat bertugas menyusun rencana strategis dan program pembangunan Desa Adat, menyusun rancangan Anggaran Pendapatan dan Belanja Desa Adat, melaksanakan program pembangunan Desa Adat, melaksanakan aturan dan/atau Pararem Desa Adat, menyelesaikan perkara adat/wicara yang terjadi dalam Wewidangan Desa Adat, mengatur penyelenggaraan kegiatan sosial dan keagamaan dalam Wewidangan Desa Adat sesuai dengan susastra agama dan tradisi masing-masing, dan melaporkan hasil pelaksanaan program dalam Paruman (rapat) Desa Adat. Selain kelembagaan pranata adat yang telah disebutkan di atas, menurut Peraturan Daerah Provinsi Bali Nomer 4 Tahun 2019 Pacalang merupakan salah satu kelembagaan pranata adat yang memiliki andil dalam penanganan konflik dalam masyarakat.

Jadi, sistem dan struktur sosial kemasyarakatan dalam masyarakat Hindu di Bali diatur oleh awigawig. Aturan Desa Adat bernama Parahyangan, Pawongan, dan Palemahan Desa Adat. Pengaturan sebagaimana dimaksud pada Pasal 14 ayat (2) Perda Provinsi Bali Nomor 4 Tahun 2019 tentang Desa Adat Bali berniat untuk memelihara kehidupan bersama di Desa Adat agar rukun, tertib, dan damai, serta berdaya guna dan berhasil guna sesuai dengan prinsip gilik saguluk, parasparo, salunglung sabayantaka, sarpanaya. 
Bermacam-macam konflik yang terjadi di Desa Adat, seperti konflik intern desa adat dan konflik antara desa adat dengan institusi lain di luar desa adat. Konflik intern yang sering terjadi adalah konflik antara desa adat dan warganya karena pelanggaran adat dengan norma yang terdapat dalam desa adat tersebut. Konflik ini sering disebut dengan konflik adat. Sedangkan konflik antar desa dengan institusi lain di luar desa yang sering terjadi soal perbatasan desa satu dengan desa lainnya, dan konflik antara desa adat dengan investor.

Permasalahan yang akan dikaji mengenai peran Pranata adat di Bali khususnya masyarakat adat lebih dikenal dengan desa adat atau banjar desa adat dalam menangani konflik. Pada hakikatnya pranata adat di Bali menerapkan prinsip ajaran agama Hindu dalam menata umatnya. Alat yang digunakan dalam menata umat atau warganya berupa awig-awig (peraturan). Sumber daripada awig-awig adalah ajaran agama Hindu dan kesepakatan rapat atau hasil keputusan rapat desa.

Pranata adat dapat membantu pemerintah pusat dan daerah dalam membangun sistem penanganan pertama guna mencegah konflik di daerah yang diidentifikasi sebagai daerah potensi konflik atau mencegah perluasan konflik di daerah yang sedang terjadi konflik. Pranata adat bisa membentuk satuan tugas khusus untuk menjalankan sistem peringatan dini berupa pengumpulan dan penyampaian informasi mengenai potensi konflik atau terjadinya konflik di daerah tertentu kepada masyarakat untuk bersama-sama mencegahnya. Pranata adat membangun sistem peringatan dini bersama pemerintah pusat dan pemerintah daerah dengan cara melakukan penelitian dan pemetaan wilayah potensi konflik, penyampaian data dan informasi mengenai konflik secara cepat dan akurat, penyelenggaraan pendidikan dan pelatihan, peningkatan dan pemanfaatan modal sosial, penguatan dan pemanfaatan fungsi intelijen sesuai dengan ketentuan peraturan perundang-undangan (Mualimin, 2014).

Pranata adat harus mendorong media massa dan media sosial untuk bersama-sama melakukan pencegahan. Pranata adat harus mendorong media massa untuk menggunakan jurnalisme damai dalam liputan-liputannya guna pencegahan konflik.

Bagi rakyat Indonesia yang heterogen ada beberapa yang masih menghargai keberadaan tradisi atau tradisi adat yang bersumber dari nilai-nilai budaya mereka. Secara langsung ataupun tidak langsung heterogenitas sosial dapat mendukung kontribusi positif dalam meningkatkan kesejahteraan masyarakat (Pratikto, 2012). Di sisi lain, dalam kehidupan nasional misalkan terdapat ketimpangan pembangunan, ketidakadilan dan kesenjangan sosial dan ekonomi, serta ketidakterkendalian dinamika kehidupan politik dapat berdampak buruk dalam heterogenitas sosial.

Pranata adat serta setiap orang dalam masyarakat wajib menjaga keadaan damai untuk masyarakat dengan cara, yaitu sebagai berikut.

a. Mengedepankan rasa toleransi dalam menghargai kebebasan melaksanakan kegiatan beragama. Pengembangan sikap toleransi ini terutama menjadi tugas pranata adat sosial dan tokoh-tokoh masyarakat setempat dan didukung oleh setiap warga masyarakat, dalam hal mencegah konflik antar pemeluk umat beragama. Di Indonesia konflik seperti ini banyak terjadi di berbagai tempat, dari konflik skala kecil hingga skala besar. Saling percaya dan menghormati antar kelompok agama menjadi kunci dalam memelihara kondisi damai dalam hubungan antar umat beragama. Terbentuknya forum komunikasi antar tokoh umat beragama dalam suatu wilayah terkecil merupakan cara efektif untuk mencegah sebuah potensi konflik muncul dan meluas. Pemerintah pusat dan pemerintah daerah membentuk forum-forum semacam ini, namum alangkah lebih bagus jika inisiatif pembentukan forum muncul dari pranata sosial setempat.

b. Menghargai keragaman suku dan budaya di lingkungan sekitar. Tugas pranata adat dan pranata sosial, serta setiap orang dalam masyarakat adalah mencegah terjadinya konflik antar suku dan etnis. Pranata adat, pranata sosial dan masyarakat luas harus berupaya sekuat tenaga agar konflik antar suku dan etnis tidak terjadi. Konflik antar suku dan etnis di Indonesia jamak terjadi. Oleh karena itu, tugas pranata adat dan pranata sosial adalah membentuk forum-forum hingga ke wilayahwilayah paling kecil untuk selalu merekatkan hubungan antara suku dan etnik dan mencegah potensi konflik muncul.

c. Menghargai manusia sesuai dengan kepercayaannya.

d. Menghormati persamaan dan hak sebagai manusia.

e. Mengembangkan lebih dalam persatuan Indonesia atas dasar Kebhinneka Tunggal Ikaan. 
f. Mengakui kebebasan dalam berpendapat. Kebebasan kita berhenti ketika menyentuh kebebasan orang lain. Jadi, tatanan adat serta masyarakat harus mendorong khalayak untuk menghargai kebebasan setiap orang.

Pranata adat memiliki peranan penting dalam upaya penanganan konflik dalam masyarakat heterogen di Indonesia dengan cara meningkatkan atau menumbuhkan rasa kebersamaan di dalam kegiatan bermasyarakat. Tumbuhnya rasa toleransi dalam masyrakat tersebut akan mengurangi terjadinya konflik dalam masyarakat. Jadi, pranata adat memiliki faktor penting dalam penanganan konflik masyrakat pentingnya toleransi dalam kehidupan bermasyarakat.

\section{SIMPULAN DAN SARAN}

\section{Simpulan}

Berdasarkan pembahasan tersebut di atas, dapat disimpulkan bahwa pengaturan Penanganan Konflik Sosial di Indonesia menurut Undang- Undang No. 7 tahun 2012 tentang Penanganan Konflik Sosial, memiliki peranan penting dalam upaya melakukan pencegahan konflik, yaitu menjaga kenyamanan dimasyarakat dan mengembangkan upaya peredaman potensi konflik di masyarakat. Dalam penanganan konflik, penghentian kekerasan fisik diberikan, status keadaan konflik ditetapkan, tindakan darurat penyelamatan dan perlindungan korban dilakukan. Penanganan konflik pada pasca konflik memiliki peranan dalam upaya mendamaikan kelompok masyarakat yang terlibat konflik, yaitu rekonsiliasi, rehabilitasi, rekonstruksi. Tatanan Adat dalam permasalahan sosial di masyarakat, sebelum ditangani secara langsung oleh pemerintah dan pemerintah daerah, tatanan adat dalam UU penanganan konflik sosial adalah lembaga adat yang diprioritaskan dalam menangani konflik sosial sesuai Pasal 41 ayat (2) UU No. 7 tahun 2012 tentang penanganan konflik sosial.

\section{Saran}

Pemerintah perlu mempelajari mengenai tatanan adat sesuai dengan yang tertera pada UU No. 7 Tahun 2012, pemerintah dan pemerintah daerah harus turun untuk lebih mengedukasi setiap elemen yang ada dalam masyarakat yang disebut pranata adat mengenai apa yang menjadi upaya pemerintah dalam mencegah konflik yang terjadi dalam masyarakat seperti yang tertuang dalam Undang- Undang No. 7 Tahun 2012. Pranata adat merupakan elemen penting dalam mengatur kehidupan bermasyarakat, sehingga pranata adat tersebut harus tegas dalam memberlakukan Undang-Undang No.7 Tahun 2012 dan aturan yang ada di daerah seperti awig-awig. Sanksi juga harus diberikan terhadap golongan masyarakat yang terindikasi memicu konflik antar kelompok masyarakat.

\section{DAFTAR PUSTAKA}

Armida. (2010). Eksistensi Lembaga Adat: Studi Kasus Lembaga Adat Melayu Jambi Tanah Pilih Pasko Batuah Kota Jambi dan Tinjauan Kritis terhadap Perda No . 5 Tahun 2007. Kontekstualita, 25(1), 113-136. Retrieved from https://jurnal.dpr.go.id/index.php/hukum/article/view/237/178

Fajar, M., \& Ahmad, Y. (2010). Dualisme Penelitian Hukum Normatif dan Hukum Empiris. Yogyakarta: Pustaka Pelajar.

Hussein, A. F. F., \& Al-Mamary, Y. H. S. (2019). Conflicts: Their Types, and Their Negative and Positive Effects on Organizations. International Journal of Scientific and Technology Research, $8(8), 10-13$.

Manarisip, M. (2012). Eksistensi Pidana Adat dalam Hukum Nasional. Lex Crimen, 1(4), 39. Retrieved from https://media.neliti.com/media/publications/3160-ID-eksistensi-pidana-adat-dalam-hukumnasional.pdf

Mualimin. (2014). Pedoman Bagi Pranata Adat dalam Penanganan Konflik Sosial. Jakarta Selatan: Pohon Cahaya.

Mulyadi, M. (2013). Pemberdayaan Masyarakat Adat Dalam Pembangunan Kehutanan (Studi Kasus Komunitas Battang di Kota Palopo, Sulawesi Selatan). Jurnal Penelitian Sosial Dan Ekonomi Kehutanan, 10(4), 224-234. Retrieved from https://media.neliti.com/media/publications/29076ID-pemberdayaan-masyarakat-adat-dalam-pembangunan-kehutanan.pdf

Pratikto, A. (2012). Pengaruh Budaya terhadap Kinerja Perekonomian. Buletin Studi Ekonomi, 17(2), 98-115. Retrieved from https://ojs.unud.ac.id/index.php/bse/article/download/2172/1371

Prawirohardjo. (1993). Ilmu Pemerintahan. Jakarta: Karya Dharma. 
Salim, H. M. (2016). Adat Sebagai Budaya Kearifan Lokal untuk Memperkuat Eksistensi Adat ke Depan. Al Daulah: Jurnal Hukum Pidana Dan Ketatanegaraan, 5(2), 244-255. https://doi.org/10.24252/ad.v5i2.4845

Samsul, I. (2014). Penguatan Lembaga Adat sebagai Lembaga Alternatif Penyelesaian Sengketa. Negara Hukum, 5(2), 128-142. https://doi.org/10.21143/jhp.vol29.no4.564

Soekanto, S., \& Mamuji, S. (1990). Penelitian Hukum Normatif: Suatu Tinjauan Singkat. Jakarta: CV. Rajawali.

Soepomo. (2000). Tentang Hukum Adat. Jakarta: Pradnya Paramita.

Suardita, I. K., \& Krisnawati, I. G. A. A. A. (2015). Pencegahan dan Penanggulangan Konflik Sosial di Bali dari Perspektif Hukum. Retrieved from https://simdos.unud.ac.id/uploads/file_penelitian_1_dir/54e6489f1f3a5c00dda067bc27adaa00.pd $\mathrm{f}$

Sudantra, I. K. (2009). Pemberdayaan Desa Adat dalam Penyelesaian Perkara di Luar Pengadilan. Denpasar: Universitas Udayana.

Tamarasari, D. (2002). Pendekatan Hukum Adat dalam Menyelesaikan Konflik Masyarakat pada Daerah Otonom. Jurnal Kriminologi Indonesia, 2(I), 37-47. Retrieved from https://www.neliti.com/publications/4219/pendekatan-hukum-adat-dalam-menyelesaikankonflik-masyarakat-pada-daerah-otonom 